\title{
Review \\ Sickle Cell Disease: A Paradigm for Venous Thrombosis Pathophysiology
}

\author{
Maria A. Lizarralde-Iragorri and Arun S. Shet * \\ Laboratory of Sickle Thrombosis and Vascular Biology, Sickle Cell Branch, National Institutes of Health, \\ Bethesda, MD 20892, USA; maria.lizarralde-iragorri@nih.gov \\ * Correspondence: arun.shet@nih.gov
}

Received: 26 June 2020; Accepted: 24 July 2020; Published: 25 July 2020

\begin{abstract}
Venous thromboembolism (VTE) is an important cause of vascular morbidity and mortality. Many risk factors have been identified for venous thrombosis that lead to alterations in blood flow, activate the vascular endothelium, and increase the propensity for blood coagulation. However, the precise molecular and cellular mechanisms that cause blood clots in the venous vasculature have not been fully elucidated. Patients with sickle cell disease (SCD) demonstrate all the risk factors for venous stasis, activated endothelium, and blood hypercoagulability, making them particularly vulnerable to VTE. In this review, we will discuss how mouse models have elucidated the complex vascular pathobiology of SCD. We review the dysregulated pathways of inflammation and coagulation in SCD and how the resultant hypercoagulable state can potentiate thrombosis through down-regulation of vascular anticoagulants. Studies of VTE pathogenesis using SCD mouse models may provide insight into the intersection between the cellular and molecular processes involving inflammation and coagulation and help to identify novel mechanistic pathways.
\end{abstract}

Keywords: venous thromboembolism (VTE); sickle cell disease (SCD); mice models; stasis; hypercoagulability; endothelial injury; inflammation

\section{Venous Thromboembolism and Sickle Cell Disease}

The third most common cause of vascular death from thrombosis in the United States is venous thromboembolism (VTE), a disorder that includes both deep vein thrombosis (DVT) and pulmonary embolism (PE) [1]. Many factors influence VTE incidence including increasing age, obesity, hospitalization, active cancer, immobility, pregnancy, estrogen therapy, and the presence of underlying inflammatory disease [2]. Our overall understanding of the molecular pathogenesis of VTE has been largely advanced by development of animal models that have been engineered to recapitulate human disease [3]. From these studies, it is apparent that activation of coagulation and inflammatory pathways are critical to VTE pathophysiology. However, the precise molecular and cellular events leading to the initiation, development, and resolution of VTE in humans is yet to be completely elucidated. In this review, we explore how the pro-inflammatory and procoagulant milieu in sickle cell disease (SCD) predisposes to VTE, and review whether elucidating these intersecting pathways may advance our understanding of the pathobiology of venous thrombosis.

SCD is the most prevalent genetic disorder worldwide, with estimates suggesting that approximately 300,000 infants are born every year with this condition [4]. It is a multisystemic disorder caused by a single point mutation in the sixth codon (c.20A $>\mathrm{T})$ of the hemoglobin gene, leading to substitution of valine for glutamic acid in the $\beta$-globin chain [5]. Sickle hemoglobin $(\mathrm{HbS})$ polymerizes when deoxygenated, forming insoluble fibers that cause "sickled" red cells and trigger a complex cascade of events leading to protean manifestations of SCD [6-8]. 
Hemolytic anemia and vaso-occlusive pain crises (VOC) are dominant clinical manifestations of SCD, but patients are also at risk for developing VTE. In support of this notion are observational studies, indicating a $25 \%$ increased VTE risk with a mean age of incidence very similar to high-risk thrombophilia patients (30 vs. $29 \mathrm{yrs}$.), which sharply contrasts with age of incidence in the general population (65 yrs.) [9-12]. Moreover, adults with wide range of sickling hemoglobinopathies have been associated with the development of VTE, from hemoglobin SS to compound heterozygous states to sickle cell trait [13]. A curious phenomenon in SCD patients is the increased overall prevalence of pulmonary embolism (PE) that occurs in the absence of detectable extremity deep venous thrombosis (DVT) suggesting either the occurrence of in situ pulmonary thrombosis [14] or classic thromboembolic PE from clot friability/instability [15]. In SCD, thrombosis also affects the arterial circulation, leading to devastating complications, such as stroke and silent cerebral infarction [16], a topic that is beyond the scope of this review.

According to Virchow, the occurrence of venous thrombosis can be predicted by a triad of blood hypercoagulability, changes in the vessel wall, and stasis [17]. All the components of Virchow's triad, i.e., hemostatic features indicative of hypercoagulable blood, cellular biology characteristic of endothelial activation/inflammation, and rheological features consistent with vascular stasis, are demonstrable in SCD patients. It is therefore unsurprising that venous and arterial thromboses are frequently documented in patients with SCD [18]. However, the exact sequence of events leading to venous thrombus formation is less clear, as is the relative contribution of blood cells/vessel wall and blood flow/stasis. Blood coagulation and innate immune responses are closely interrelated, thus the presence of dysregulation of inflammatory and coagulation pathways in SCD suggests that they contribute to VTE pathophysiology. Key amongst these dysregulated processes is the overexpression of tissue factor (TF), the principal trigger of human coagulation in vivo, and a coagulant protein critical to atherothrombosis [19]. The generation of thrombin in SCD occurs via initiation of coagulation by the TF/VIIa pathway and the contact pathway [20,21]. Sickle blood also exhibits increased TF-dependent procoagulant activity, and consequently increased thrombin generation, as reflected by elevated levels of thrombin anti-thrombin complexes (TAT), prothrombin fragment 1.2 (F1.2), and D-dimers [22-25]. Since the molecular and cellular events involved in vascular thrombosis are complex and involve many overlapping pathways, the use of murine models could provide important insight into the processes, particularly those dysregulated inflammatory and coagulation pathways in SCD [26] that are critical to VTE pathogenesis.

\section{Animal Models of Disease Pathophysiology}

Elucidating the molecular and cellular events leading to vascular thrombogenesis has largely been advanced by the use of various different animal models but for the purpose of this review, we focus only on studies of murine models. Murine models have distinct advantages, and it is worth noting that, among the murine models in vogue, no single model unequivocally replicates human venous thrombosis pathophysiology. Similarly, murine models of SCD have elucidated the multistep mechanistic processes thought to underlie the development of acute vaso-occlusive pain crisis (VOC) in patients with SCD. Again, whether these murine vascular events that are induced by infusion of cytokines or heme truly represent spontaneous VOC in humans is largely unknown. Regardless of these considerations, murine models offer unique advantages, such as low maintenance cost, a short life span, rapid reproduction rate, and ease of genetic manipulation, explaining their widespread use in clinical investigation.

\subsection{Murine Models of VTE}

Excepting in surgery associated DVT, histopathological examination of human vein thrombosis in the region of the clot seldom indicates evidence for vein injury. Thus, human DVT differs from DVT in animal models, where injury of the vein, even if only by ligation, is usually an initiating event. From this perspective, describing the various methodologies utilized to develop vascular models that replicate 
human disease pathophysiology provides important contextual information. Surgical exposure of a target vein and provoking venous thrombosis by inducing endothelial inflammation/injury is an important limitation of most mouse models. A major concern here is that the nature and extent of vascular injury is variable, and greatly influences subendothelial TF exposure. In most murine VTE models, the inferior vena cava (IVC) is used to induce venous thrombosis, due to its size and easy accessibility. The IVC stenosis approach possibly represents human pathophysiology more accurately by minimizing endothelial injury typically associated with previous models.

Murine models incorporating heritable thrombophilia mutations have yielded insight into the pathophysiology of VTE induced by abnormal blood coagulation [27]. Unfortunately, many of these studies fail to capture the effects of prolonged exposure of the vascular endothelium to thrombophilia that possibly contribute to chronic venous vasculopathy [28]. Blood stasis is another predictor of VTE in humans, as noted by the increased propensity for VTE in individuals with prolonged immobility. VTE models recapitulate stasis-induced VTE by the use of a surgical ligature to reduce the IVC lumen by 80-90\%. Reduction of the vessel lumen does not denude the endothelium; however, the endothelium is still activated, and releases the von Willebrand factor (vWF) and P-selectin from the Weibel-Palade bodies. Information regarding thrombus size and composition, thrombus resolution and eventual vessel recanalization is forthcoming, but the lack of valves in the IVC is a distinct disadvantage to studying DVT [3,29].

Transgenesis and gene targeting techniques to make an organism's genes inoperative (knock out) or mutate them or replace them with genes from another species have led to an understanding of the events occurring during vascular thrombosis and fibrinolysis [28]. Since VTE is influenced by heritable or acquired thrombophilia genes, inducing these genetic mutations in mice may be used to study the direct effects of these gene mutations on VTE development. Depending on the technique used to induce thrombogenesis, one can study thrombus formation resulting from: (1) venous stasis, (2) endothelial injury, or (3) induced localized hypercoagulability (Table 1). 
Table 1. Venous thromboembolism (VTE) mouse models.

\begin{tabular}{|c|c|c|c|}
\hline Venous Thrombosis Murine Model & Characteristics & Disadvantages & Mechanisms of Thrombus Formation \\
\hline Venous stasis but ligation induced injury & $\begin{array}{l}\text { Complete and permanent occlusion of } \\
\text { the inferior vena cava (IVC) and the } \\
\text { venous flow. }\end{array}$ & $\begin{array}{l}\text { The absence of blood flow, which not } \\
\text { reproduce the clinical scenario where a } \\
\text { thrombus is non-occlusive. }\end{array}$ & $\begin{array}{l}\text { The combination of venous stasis and } \\
\text { endothelial injury with upregulated expression } \\
\text { of endothelial adhesion/procoagulant molecules } \\
\text { imitates thrombosis. }\end{array}$ \\
\hline Venous stenosis with no injury & $\begin{array}{l}\text { Preservation but markedly reduced } \\
\text { venous blood flow and minimal } \\
\text { endothelial injury. }\end{array}$ & $\begin{array}{l}\text { Occasional failure to induce persistent } \\
\text { thrombosis and variability in thrombus size. }\end{array}$ & $\begin{array}{l}\text { Endothelial activation, recruitment of immune } \\
\text { cells and platelets, initiate thrombosis which is } \\
\text { augmented by stasis. }\end{array}$ \\
\hline Ferric chloride induced injury & $\begin{array}{l}\text { Surgical exposure of IVC followed by } \\
\text { topical application of ferric chloride. }\end{array}$ & $\begin{array}{l}\text { Endothelial injury induced by the chemical } \\
\text { irritant stimulus. Exposure time and } \\
\text { concentration influence size and thrombus } \\
\text { growth dynamics. }\end{array}$ & Oxidative damage to vascular endothelial cells. \\
\hline Rose Bengal induced injury & $\begin{array}{l}\text { This model is mainly used to induce } \\
\text { acute thrombosis. }\end{array}$ & $\begin{array}{l}\text { Endothelial injury by oxygen free radical } \\
\text { induced oxidative stress. }\end{array}$ & $\begin{array}{l}\text { Endothelial activation/injury with subsequent } \\
\text { induce thrombus formation. }\end{array}$ \\
\hline $\begin{array}{l}\text { Electrolytic vein injury with local } \\
\text { hypercoagulability }\end{array}$ & $\begin{array}{l}\text { Non-occlusive thrombosis model that } \\
\text { enables to study the acute and chronic } \\
\text { deep vein thrombosis (DVT). }\end{array}$ & $\begin{array}{l}\text { Substantial endothelial and vessel wall } \\
\text { damage due to the needle access and lengthy } \\
\text { procedural time. }\end{array}$ & $\begin{array}{l}\text { Thrombus formation takes place after } \\
\text { endothelial cell activation/injury, but blood flow } \\
\text { is unaltered. }\end{array}$ \\
\hline
\end{tabular}




\subsection{Sickle Cell Disease Animal Models}

Transgenic mice expressing $\beta S$-hemoglobin have enhanced our understanding of different clinical aspects of SCD, such as anemia, vaso-occlusion, and chronic organ damage [30,31]. In particular, subjecting mice to hypoxia followed by reoxygenation or infusion of hemoglobin appears to successfully mimic VOC in human SCD, and have provided insight into vascular pathobiology SCD [32-35]. However, the choice of murine model can influence study results and outcome. For instance, $\beta^{S A D}$ mice tolerate hypoxia induced events relatively well and $A \beta^{S}$ Antilles mice can be surgically manipulated to study vaso-occlusion [34]. The more severe humanized models do not tolerate either surgical manipulation or hypoxia. Moreover, the mouse background and basal murine hemoglobin expression can interfere with $\mathrm{HbS}$ polymerization and mask the true phenotype of sickling hemoglobinopathies [30,36].

Humanized transgenic mice models have, at least to a certain extent, overcome pathophysiological limitations, permitting the conduct of mechanistic studies. The Townes and Berkeley(BERK) sickle mouse models show characteristic features of SCD, including severe anemia, hemolysis, inflammation, and endothelial activation [36,37]. Importantly, they also display biochemical features consistent with the sickle hypercoagulable state (see Table 2), e.g., increased thrombin generation [38,39], depletion of the natural anticoagulants [28,38], increased TF expression [40], and abnormalities in fibrinolytic activity [15]. Evidence of thrombosis can also be found in multiple organs of sickle cell mice [41], and hypoxia further enhances thrombosis in their pulmonary vasculature [42]. Insights into molecular and cellular events occurring at the fluid-wall interface of blood vessels that are critical to both VTE and SCD pathophysiology have been gleaned from several of these models, as discussed further below. 
Table 2. Sickle cell disease (SCD) mouse models.

\begin{tabular}{|c|c|c|c|}
\hline Mice Model & Type of Transgene & Phenotype & Limitations \\
\hline $\begin{array}{c}\beta^{\text {SAD }} \\
\text { NY1DD }\end{array}$ & $\begin{array}{c}\text { Human } \alpha 2 \text {-globin linked to a human } \\
\beta \text {-globin LCR; human } \beta \text { SAD-globin gene } \\
\text { carrying Antilles and Hb D-Punjab } \\
(\beta 121 \text { Gln) variants linked to a human } \\
\beta \text {-globin LCR }\end{array}$ & $\begin{array}{c}\text { Mild phenotype } \\
\text { Increased red cell density } \\
\text { Low oxygen affinity and an enhanced polymerization potential } \\
\text { Under hypoxia conditions, these mice express a more severe pathology } \\
\text { Mice develop priapism, kidney defects, and shortened survival } \\
\text { Moderate phenotype }\end{array}$ & $\begin{array}{l}\text { Not anemic } \\
\text { Mouse hemoglobin expression } \\
\text { Genetic thalassemia background }\end{array}$ \\
\hline $\begin{array}{l}\mathrm{A} \beta^{\mathrm{S} \text { Antilles }} \\
\text { S+SAntilles }\end{array}$ & $\begin{array}{l}\text { Human } \alpha 2 \text {-globin and } \beta S \text { Antilles-globin } \\
\text { variant ( } \beta 23 \text { 2lle), each linked to } \\
\text { individual LCR HSII fragments }\end{array}$ & $\begin{array}{c}\text { Anemic mice with low solubility and low oxygen affinity } \\
\text { Slightly reduced hematocrit and haptoglobin levels } \\
\text { Exhibit symptoms of VOC } \\
\text { Increased reticulocyte count and plasma hemoglobin } \\
\text { Severe phenotype }\end{array}$ & $\begin{array}{l}\text { Mouse hemoglobin expression } \\
\text { Genetic thalassemia background }\end{array}$ \\
\hline $\begin{array}{l}\text { Berkeley model } \\
\text { SS-BERK }\end{array}$ & $\begin{array}{c}\text { Mini-LCR expressing human } \alpha 1, \mathrm{G} \gamma, \mathrm{A} \gamma \\
\delta, \beta S \text { globins on a murine } \alpha \text { - and } \\
\beta \text {-globin-deficient background }\end{array}$ & $\begin{array}{c}\text { Express almost exclusively human sickle hemoglobin } \\
\text { Sickle red blood cells (RBCs), intravascular hemolysis, reticulocytosis, } \\
\text { severe anemia, leukocytosis, elevation of inflammatory cytokines, } \\
\text { multiorgan infarcts, and pulmonary congestion } \\
\text { Exhibit VOCs, I/R pathophysiology and increased inflammatory response } \\
\text { Hyperalgesia }\end{array}$ & $\begin{array}{l}\text { Low mean corpuscular hemoglobin } \\
\quad \text { concentrations }(\mathrm{MCHC}) \\
\text { Enlarged spleen with compensatory } \\
\quad \text { extramedullary hematopoiesis }\end{array}$ \\
\hline Townes model & $\begin{array}{l}\text { Human mini-LCR expressing human } \alpha 1, \\
\text { A } \gamma, \beta S \text { globins on a murine } \alpha \text { - and } \\
\beta \text {-globin-deficient background }\end{array}$ & $\begin{array}{c}\text { Severe phenotype } \\
\text { Expansion of red pulp, pooling of sinusoidal RBCs, vaso-occlusion, and } \\
\text { loss of lymphoid follicular structure } \\
\text { Marked reduction in RBC counts, Hb concentrations, PCVs, and a } \\
\text { significantly increased reticulocyte count } \\
\text { Hyperalgesia }\end{array}$ & $\begin{array}{l}\text { Enlarged spleen with compensatory } \\
\text { extramedullary hematopoiesis }\end{array}$ \\
\hline
\end{tabular}

I/R: Ischemia/Reperfusion; LCR: Locus control region; MCHC: Mean corpuscular hemoglobin concentrations; PCV: Packed cell volume, VOC: Vaso-occlusive crisis. 


\section{Insights into VTE Pathophysiology Using SCD Mouse Models}

Since all three components of Virchow's triad are encountered in SCD (Figure 1), employing sickle cell mouse models to enhance our understanding of VTE pathobiology appears to be specifically advantageous. From this perspective, reviewing the dysregulated coagulation and inflammation pathways that probably facilitate VTE development in patients with SCD is relevant.

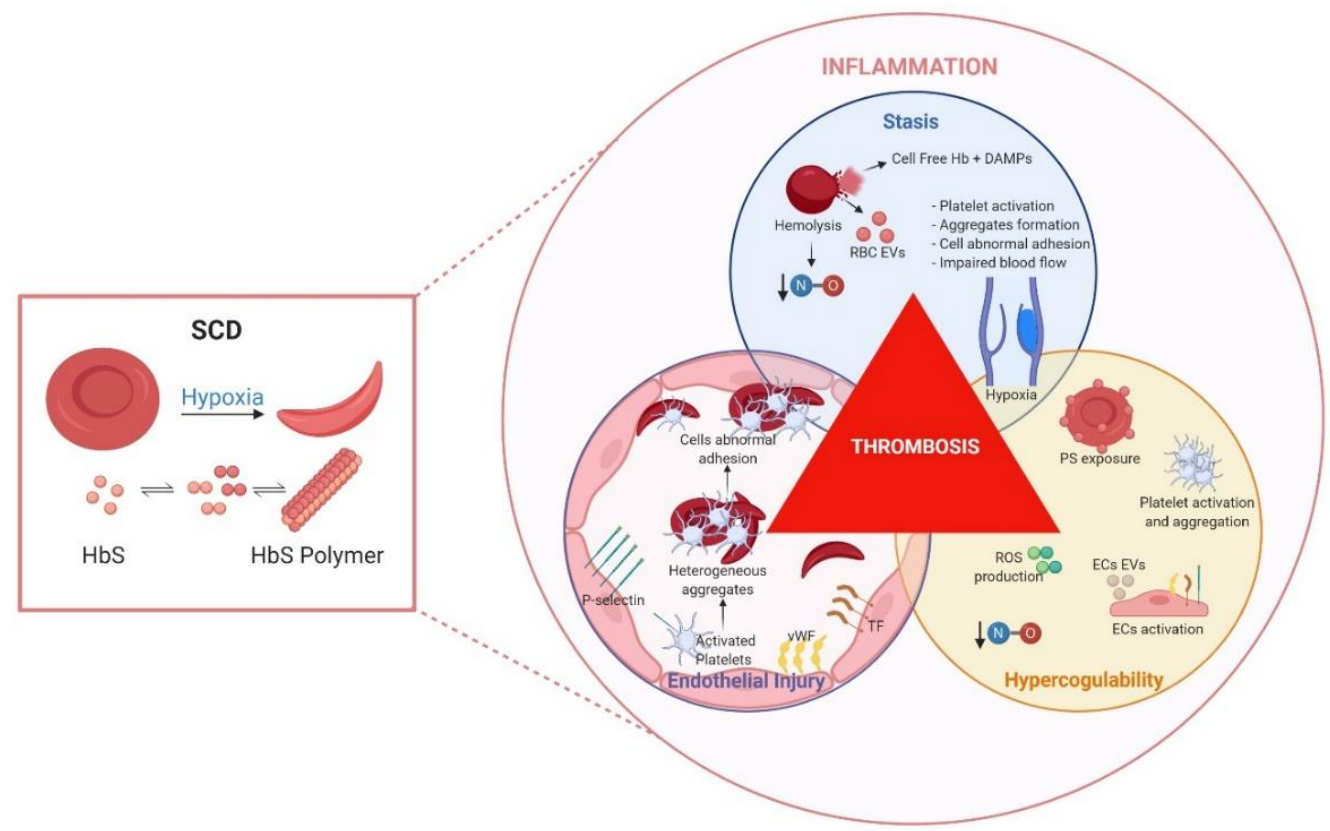

Figure 1. Sickle cell disease factors that contribute to thrombosis.

The root cause of sickle cell pathology is the polymerization of $\mathrm{HbS}$, a process influenced among other factors largely by allosteric effectors and delayed transit time of sickled red blood cells (RBCs) in the microcirculation. Consequently, the sickle RBC becomes fragile, less deformable, and prone to lysis, releasing proinflammatory hemoglobin and extracellular vesicles (EVs). Moreover, frequent episodes of vaso-occlusive crises in patients lead to ischemia, followed by reperfusion, which is profoundly inflammatory to blood and vascular endothelial cells. The molecular, cellular and plasmatic events occurring might be represented by Virchow's triad that summarizes factors predisposing to pathological venous thrombosis. Although the exact sequence of events is unclear, it appears that activation of coagulation by TF is an important trigger of clinical thrombosis. Endothelial cell (EC) injury, as a consequence of plasma cell free-heme induces abnormal surface expression of tissue factor (TF), P-selectin, von Willebrand Factor (vWF). Moreover, reactive oxidative species (ROS) production, lowered vascular nitric oxide (NO), and endothelial/leucocyte activation leads to release of other damage-associated molecular patterns (DAMPs), EVs, and formation of aggregates that support procoagulant and proadhesive vascular phenomena. Several other vascular factors altering $\mathrm{HbS}$ polymerization and red cell delay time impair microvascular blood flow, causing venous stasis and augmenting prothrombotic phenomena. Taken together, these events collectively initiate and propagate venous thrombosis and lead to clinical deep vein thrombosis or pulmonary embolism in SCD. Figure created with BioRender.com.

\subsection{Hypercoagulability}

A hypercoagulable state or hypercoagulability describes a condition where blood clots spontaneously with little or no provocation. Pathological hypercoagulability might occur, due to increased procoagulant proteins, the presence of clotting protein variants that are more procoagulant, decreased anticoagulant proteins, and/or decreased fibrinolysis. The mechanism by which intravascular 
venous thrombosis occurs is not fully elucidated, but is generally agreed to involve $\mathrm{TF}$, as the initiator of pathological coagulation [43]. Several models in which "blood borne" TF, probably associated with blood cells or EV, provide support for this notion [44,45]. In these studies, depending on the type of vessel injury induced and the vascular bed involved, blood borne TF contributed little to stasis induced venous thrombosis, indicating that TF in the vascular clot was derived from the vessel wall [46]. This evidence bolsters support for the importance of endothelial TF expression and pathological thrombosis in SCD. Physiological processes such as shear stress, inflammation, and hypoxia can promote vascular luminal TF expression, and subsequent fibrin deposition in mouse models [47,48]. Moreover, in vivo and in vitro evidence of the pro-inflammatory effects of intravascular heme in SCD demonstrate its capacity to elicit pathological TF expression in SCD patients and murine models (see Section 3.2 below) [25,40,49-51]. Evidence for cell and extracellular vesicle (EV) associated-TF, in patients at baseline and during VOC [25], indicate the pathophysiological role that EV-associated TF plays in murine models of VTE [52-55]. Surface TF expression on vascular endothelial and blood cells is associated with procoagulant effects and proinflammatory signaling [56]. In murine SCD models, TF originating from hematopoietic cells and vascular endothelial cells appear to have distinct effects on systemic inflammation and hypercoagulability $[39,57,58]$. Collectively, these studies implicate TF as a critical mediator of vascular inflammation and thrombotic end-organ damage in murine models of SCD and suggest that appropriately targeted anticoagulation treatment might lead to improved clinical outcomes in sickle cell patients.

Unlike the TF pathway, the contact pathway lacks a physiological role in hemostasis, but it appears to be involved in pathological venous thrombosis. In support of this idea is the observation that FXII deficiency in mice led to attenuation of thrombosis, and conferred a survival advantage following the induction of lethal pulmonary embolism [59]. FXI deficiency and inhibition of FXII-dependent FXI activation does not impact thrombin generation in sickle cell mice, but FXII deficiency attenuates thrombin generation in sickle mice [60]. Cell death during I/R injury [61] and release of histone-DNA complexes (nucleosomes) initiate inflammation, and can propagate thrombosis and lead to fibrin deposition [62,63]. In SCD patients, the presence of the following substances in blood, e.g., negatively charged cell surface membranes phosphatidylserine (PS) exposure on red and other cell-derived EVs, nucleic acids [64], and platelet derived polyphosphates, explain contact pathway activation $[18,21,65,66]$. Moreover, the presence of these activating substances during acute complications and the subsequent low-grade thrombin generation suggests the involvement of this pathway in VOC pathophysiology. Regardless, at present there is no evidence for a direct effect of contact pathway activation on VTE development in both humans and mouse models of SCD.

The activation of both TF and contact pathways leads to the accumulation of intravascular thrombin, a potent thromboinflammatory signal. Murine coagulation models have delineated the critical role of thrombin in the vascular pathobiology of VTE [67]. In BERK SCD mice, elegant studies that attenuated thrombin either via genetic manipulation or antisense oligonucleotides have demonstrated its role in sickle vasculopathy. Diminished thrombin markedly reduced plasma inflammatory markers, D-dimers and endothelial cell dysfunction [68]. Moreover, histopathological analysis performed on at least 12-month aged prothrombin deficient mice revealed attenuation of chronic vasculopathy and target organ damage, compared to SCD mice with normal prothrombin levels. Prolonged exposure of the vasculature to thrombin seemingly led to organ vasculopathy, that was likely mediated via vascular endothelial protease activated receptors (PARs). Interestingly, inhibiting PAR-1 either pharmacologically or using PAR-1 non-hematopoietic cell-deficient mice, significantly attenuated heme-induced microvascular stasis in a sickle mouse model of VOC [69]. TF inhibition also led to similar findings in the pulmonary microvasculature, suggesting that coagulation may play a role in microvascular stasis.

As described below, sickle hemolysis can consume vascular nitric oxide (NO) and plasma arginine, inducing profound endothelial and vascular dysfunction [70,71]. In particular, the endothelial hemostatic balance shifts to a thrombotic phenotype, with the upregulation of procoagulant molecules 
and the downregulation of anticoagulant molecules. Unsurprisingly, several studies have reported significant reduction of the anticoagulant factors, protein $C$ and $S$ levels in both children and adults with SCD in steady state, compared with controls [72,73]. Lowered protein C activity levels in SCD patients that decrease further during VOC, suggests that protein $\mathrm{C}$ may be consumed acutely and chronically. Another key protein of the protein C pathway is thrombomodulin (TM), an endothelial-bound protein which activates protein C [74]. At baseline, SCD mice exhibit elevated TM and endothelial protein C receptor (EPCR) expression, suggesting a compensatory up-regulation of these proteins in SCD [41]. While these data may seem preliminary, they provide evidence that acquired defects in anticoagulant proteins play a role in the multi-causal pathway of VTE pathogenesis in SCD.

\subsection{Inflammation and Endothelial Injury}

As alluded to before (see Section 3.1 above), healthy endothelium expresses anticoagulants, such as the TF pathway inhibitor (TFPI), TM, EPCR, and heparin-like proteoglycans, and ectonucleotidase CD39/NTPDase1, which metabolizes the platelet agonist ADP [75]. Moreover, the release of endothelial $\mathrm{NO}$ and prostacyclin is inhibitory to platelets. Several germline encoded pattern recognition receptors (PRR) e.g., the Toll-like receptors (TLR), the C-type lectin receptors, and the nucleotide binding domain-like receptors (NLR) mediate innate and protective immune responses [76]. In SCD, host-derived PRR activators [77] trigger these receptor pathways leading to sterile inflammation and immunothrombosis. Designated DAMP molecules (e.g., cell-free hemoglobin, high-mobility group box 1 (HMGB1) and extracellular purine nucleotides) play a fundamental role in VTE pathophysiology [77-79] and also seem to drive SCD pathophysiology $[26,61,80,81]$. Since the regulation of coagulation in non-inflammatory states is likely to be different from inflammation driven coagulation, understanding how venous thrombosis occurs as part of the inflammatory response is critical to achieving insight into the pathogenesis of hypercoagulability in SCD.

Hemolytic disorders characterized by intravascular hemolysis exhibit a variety of clinical symptoms including vascular thrombosis. Cell-free heme, an erythrocyte DAMP, induces a procoagulant endothelial phenotype due to surface expression of TF, vWF, and P-selectin and downregulation of TM [40,49,80,82-85]. Endothelial activation by heme occurs via TLR-4 signaling or by direct toxicity from erythrocyte derived EVs $[82,86]$. TLR-4-mediated activation of nuclear factor- $\mathrm{kB}$ transcription factor activity also upregulates endothelial cytokine generation (tumor necrosis factor-alpha (TNF- $\alpha$ ) and interleukin1-beta (IL-1 $\beta$ ), as well as TF expression [82,87]. Furthermore, heme induces assembly of the nucleotide-binding domain-like receptor protein 3 (NLRP3) inflammasome in endothelial cells and leukocytes, with the consequent secretion of IL-1 $\beta[26,77,88,89]$. Finally, heme can activate complement via TLRs and P-selectin, leading to deposition of C3 on glomerular and hepatic endothelial cells and subsequent microvascular thrombosis [83,90]. Complement mediated vascular injury follows hemolytic crises and delayed hemolytic transfusion reactions in SCD patients [91], which, taken together with the observations in mice that complement directly activates platelets and TF to mediate venous thrombosis [92], suggests a role for investigating C5a targeted therapy. Although intravascular heme is rapidly bound by circulating haptoglobin and hemopexin in healthy individuals, these proteins are depleted in SCD patients [93] and replacement of either haptoglobin or hemopexin in SCD mice leads to a reduction in VOC [94]. The reticuloendothelial capacity for endocytosis and degradation of these heme binding protein moieties is also augmented by the upregulation of heme oxygenase 1 (HO-1). Interestingly, increased $\mathrm{HO}-1$ activity in mice transplanted with sickle bone marrow appears to offer some protection from injury induced carotid artery thrombosis, although its protective effect against venous thrombosis is unknown [95].

High mobility group box 1 (HMGB1), a chromatin-binding protein responsible for maintaining DNA structure, is released by activated immune cells or necrotic tissues and plays a role in thrombosis by signaling through TLR4 [96]. Circulating HMGB1 derived from platelets recruits' monocytes, primes the leukocyte inflammasome inducing NETosis and TF production, eventually leading to increased platelet aggregation and VTE [78]. Interestingly, plasma HMGB1 is increased in both 
humans and mice with SCD, and sickle patient plasma demonstrates increased HMGB1-dependent TLR4 activity compared with control plasma $[89,97]$. Activation of the neutrophil inflammasome by heme leads to NETosis and release of neutrophil extracellular traps (NETs) [98], an important immune response mechanism that has a role in VTE pathogenesis by acting as a scaffold for fibrin and assembly of coagulation complexes [99]. NETs activate platelets and enhance the recruitment of leucocytes via the platelet glycoprotein Ib $\alpha$ receptor, a process facilitating blood coagulation and thrombus propagation $[100,101]$. Platelet activation promotes adhesive interactions between SS RBCs and endothelial cells, and facilitates formation of aggregates with RBCs, monocytes and neutrophils [22,102-106], which, by hindering the microvascular blood flow, also augment stasis. Heterotypic aggregates are facilitated by protein-protein interactions between E-selectin and E-selectin ligand, which, in SCD mice, activates the leukocyte integrin $\alpha \mathrm{M} \beta 2$ [107].

Although platelet activation and alterations of platelet function in SCD are frequently described, the fundamental basis for these observations is less clear. Macro-thrombocytosis and platelet hyperresponsiveness to submaximal doses of thrombin in vitro have been observed in both humans [108] and SCD mouse models [109]. Both SCD patients and murine models also consistently demonstrate platelet NLRP3 inflammasome activity, suggesting an autocrine feedback loop for IL-1 $\beta$, driven by the priming of innate immune and endothelial cells [88,89]. IL-1 $\beta$ derived from platelets is released mainly as extracellular vesicles through mechanisms dependent on NLRP3 activation that are triggered by mitochondrial ROS [88]. DAMPs, such as heme, can directly activate platelets by binding with the glycocalicin domain of GP1b $\alpha$ [110] or activate the platelet NLRP3 inflammasome [89]. Other DAMPs released during ischemia reperfusion injury, i.e., cell-free DNA and histone also activate platelets via their TLRs, leading to thrombin generation [111]. Given the evidence derived from randomized clinical studies showing a 30 to $50 \%$ risk reduction in VTE by primary or secondary thromboprophylaxis with ASA [112], it is reasonable to assume that platelet activation in SCD may play a role in VTE pathophysiology. Complement mediated platelet activation contributes to venous thrombosis in murine models, providing another link between innate immunity and coagulation [92]. Activated platelets form homotypic and heterotypic cell-aggregates, and platelet-neutrophil aggregates contribute to pulmonary arteriolar microemboli and stasis (see below) $[103,105,106]$. Autopsy evidence of dense platelet-rich thrombi in the pulmonary vasculature in over half of the SCD patients experiencing acute chest syndrome (ACS) [113], coupled with the findings of pulmonary arteriolar microthrombi in murine models of ACS [114], indicate that in situ thrombosis in the lung involves platelets. In addition, murine SCD models exhibit higher pulmonary vein TF expression, which is augmented by $\mathrm{I} / \mathrm{R}[42,87]$, suggesting vulnerability of the pulmonary vasculature to in situ thrombosis [115]. These findings are directly in line with the clinical observation of in situ pulmonary thrombosis without detectable DVT in individuals with sickle cell disease $[9,14,113]$ and trait [116]. Finally, thromboinflammation involves the platelet C-type lectin-like receptor 2 (CLEC-2), and in the IVC thrombosis model, CLEC-2 deficient mice appear to be protected from developing DVT [117]. Investigating a possible role for CLEC-2 and its ligand, podoplanin, using SCD mice may identify a novel therapeutic target in SCD.

\subsection{Blood Stasis}

Sickle red cells demonstrate increased endothelial adherence leading to stasis, which in combination with hypoxia promotes sickling in the venous circulation and predisposes to VOC. Murine models provide specific evidence for sluggish blood flow and "logjamming" in the post capillary venules [118]. Endothelial surface expression of cell adhesion molecules (intercellular adhesion molecule (ICAM) and vascular cell adhesion protein (VCAM) and selectins (E and P-selectin) is important for VOC and VTE pathophysiology $[33,50,119]$. Abnormal cell surface P-selectin expression on endothelial cells and platelets in SCD, facilitates homo/heterotypic cell-cell interactions and aggregate formation, further worsening stasis and vaso-occlusion [114,120-123]. Interestingly, stasis-induced IVC thrombosis does not develop in P-selectin-deficient mice, due to a failure in leukocyte recruitment and diminished leukocyte-vessel wall endothelial interactions [123]. The clinical relevance of these observations 
is supported by the findings of reduced VOC events in SCD patients, following treatment with crizanlizumab, a monoclonal antibody against P-selectin [124]. Several alternate P-selectin inhibitors are undergoing evaluation in animal models or humans, to either modulate or treat SCD [125]. Studies of these inhibitors in SCD may be indicated to see whether there is diminished stasis and lowered VTE frequency.

Under healthy conditions, the valve pocket endothelium has a thromboresistant phenotype consisting of increased EPCR and TM expression, and reduced VWF, which helps to prevent thrombosis [126]. Otherwise, vorticial blood flow, low oxygen tension, and stasis would lead to frequent valve pocket sinus thrombosis. Increased P-selectin and TF expression in response to hypoxia, possibly explains higher expression of these molecules on endothelial vein valve sinus pockets, and why these are usually the sites where thrombosis occurs [3]. Similarly, endothelial inflammation in SCD leads to increased TF and P-selectin expression and release of vWF that could promote small thrombi within the valve pocket, which, growing slowly over days to weeks, may eventually completely occlude the vessel. Interestingly, the venous thrombus in an IVC stasis model in SCD mice demonstrated ultrastructural differences with higher amounts of fibrinous material and red cell entrapment with extensive sickling [15]. In ex vivo sickle whole blood clots, the number of RBCs extruded from the clot was also significantly reduced, compared with the number released from sickle cell trait and non-sickle clots in both mice and humans. In addition, whole blood sickle clots were resistant to fibrinolysis by tissue plasminogen activator and RBC exchange transiently reversed this, in part by decreasing platelet-derived PAI-1. There is a growing appreciation of the role of red cells in thrombosis, in particular, how they influence clot size, permeability to fibrinolytic enzymes, and clot friability [127]. Moreover, appreciation of the role of red cell ligands, i.e., FasL-FasR, that mediate platelet-RBC interactions and facilitate VTE [128], suggest the potential discovery of novel mechanisms relevant to SCD.

\section{Perspectives}

A particularly vexing problem is that SCD mice do not spontaneously develop VTE, as patients with SCD do. Whether the absence of this phenotype simply reflects a failure to systematically document these occurrences or a fundamental difference between mice and humans is currently unknown. In addition, the mechanisms underlying the development of chronic venous vasculopathy, i.e., post-thrombotic syndrome, valvular venous insufficiency and leg ulceration in those experiencing DVT, and chronic thromboembolic pulmonary hypertension (CTEPH) in those experiencing PE are also unclear. The complex vascular pathobiological events occurring in SCD, particularly those concerning VTE, could be unraveled by developing murine models that recreate human disease pathophysiology with greater fidelity. Enhancing the efforts to develop additional SCD mouse models that are optimized to study DVT, PE and in-situ pulmonary thrombosis may therefore advance the field. A greater appreciation of these processes in SCD could also be gained by studying longitudinal cohorts of SCD patients experiencing thrombosis. Moreover, these studies could be augmented with investigations in animal models that are designed to provide mechanistic insights into the pathophysiology of chronic venous vasculopathy and permit manipulations that are impossible in human subjects. This synergy could lead to elucidation of the relative contributions of inflammatory and coagulation pathways and reveal novel mechanisms of VTE pathogenesis and venous vasculopathy. Thus, the murine models of SCD could advance our understanding of the occurrence of chronic complications of VTE, i.e., post-thrombotic syndrome and chronic thromboembolic pulmonary hypertension.

Apparently, hemolysis driven inflammatory and coagulation processes, are insufficient to explain VTE risk in the entire spectrum of SCD patients. All SCD genotypes with variable $\mathrm{HbS}$ sickling severity share a similarly high risk of VTE, which is challenging to explain if sickling related intravascular hemolysis truly drives VTE pathophysiology. Less severe SCD genotypes with low grade sickling induced hemolysis, such as heterozygote for $\mathrm{HbS}(\mathrm{HbSC})$ disease and $\mathrm{S} / \mathrm{Beta}^{+}$thalassemia, experience frequent thromboembolic events; sickle cell trait individuals having an $\mathrm{HbS}$ fraction of $\sim 35-40 \%$ exhibit 
a twofold higher risk of PE, compared with ethnic controls $[13,116,129]$. Therefore, additional studies are required to understand factors, such as higher hemoglobin and hitherto unappreciated genetic or environmental factors, that may explain this increased propensity for VTE. For instance, studies in SCD mice that are P-selectin deficient [120] could unravel the phenotypic heterogeneity of thrombosis in SCD induced by genetic variations in P-selectin. Moreover, environmental and age induced genetic variation may explain the development of a prothrombotic state $[130,131]$. Exploring these intriguing clinical observations could provide mechanistic insight into VTE and help to develop therapeutic solutions that would advance patient care and improve quality of life. Finally, in the context of COVID-19, elucidating the mechanisms of sepsis mediated coagulopathy has become highly relevant, since it predicts adverse outcomes [132]. Given the preexistent inflammation and coagulation dysregulation ongoing in SCD patients at baseline, it is possible that COVID-19 associated coagulopathy may worsen outcomes in these patients. Thus, studies of the effects of SARS-CoV2 infection in murine models of SCD might provide insight into the dysregulation of thromboinflammatory processes associated with these two diseases.

\section{Conclusions}

It is clear from human population studies, that coagulation factor or natural anticoagulant factor levels influence the risk of venous thrombosis, but it is equally clear that other factors are also contributory. An increased recognition that inflammatory diseases are associated with high risk for venous thrombosis suggests that innate inflammatory and coagulation responses are pathophysiologically relevant to this process. In addition, the complex multifactorial nature of venous thrombosis suggests that several risk factors, e.g., cancer, obesity, and a sedentary lifestyle, effect the likelihood of its development. Attempting to understand the complex genetic and environmental risk factors that influence VTE in complex inflammatory disorders could provide an opportunity to understand how these interrelated pathways initiate and propagate VTE. Dysregulated inflammation and overactive coagulation in SCD result in a triad of hypercoagulability, vessel wall dysfunction, and stasis. This unique prothrombotic milieu in SCD provides an opportunity to gain fundamental insights into the molecular and cellular aspects of VTE pathophysiology. Moreover, advancing our understanding of the mechanisms involved in chronic venous vasculopathy could lead to the development of new treatments and reduce VTE associated morbidity and mortality.

Author Contributions: Writing-original draft preparation, M.A.L.-I.; writing-review and editing, A.S.S. All authors have read and agreed to the published version of the manuscript.

Funding: This work was supported by the Intramural Research Program of the National Heart, Lung, and Blood Institute, National Institutes of Health.

Conflicts of Interest: The authors declare no conflict of interest.

\section{Abbreviations}

$\begin{array}{ll}\text { ACS } & \text { Acute chest syndrome } \\ \text { ADP } & \text { Adenosine diphosphate } \\ \text { BERK } & \text { Berkeley mouse } \\ \text { CLEC-2 } & \text { Platelet C-type lectin-like receptor } 2 \\ \text { CTEPH } & \text { Chronic thromboembolic pulmonary hypertension } \\ \text { DAMPs } & \text { Damage-associated molecular patterns } \\ \text { DNA } & \text { Deoxyribonucleic acid } \\ \text { DVT } & \text { Deep venous thrombosis } \\ \text { ECs } & \text { Endothelial cells } \\ \text { EPCR } & \text { Endothelial protein C receptor }\end{array}$




\begin{tabular}{|c|c|}
\hline EVs & Extracellular vesicles \\
\hline F1.2 & Prothrombin factor 1.2 \\
\hline $\mathrm{Hb}$ & Hemoglobin \\
\hline $\mathrm{HbSC}$ & Heterozygote for $\mathrm{HbS}$ \\
\hline $\mathrm{HbSS}$ & Homozygote for $\mathrm{HbS}$ \\
\hline $\mathrm{HbS}$ & Hemoglobin S \\
\hline HbSAntilles & Hemoglobin S Antilles mice model \\
\hline HMGB1 & High-mobility group box 1 protein \\
\hline $\mathrm{HO}-1$ & Heme oxygenase 1 \\
\hline $\mathrm{I} / \mathrm{R}$ & Ischemia/Reperfusion \\
\hline ICAM & Intercellular Adhesion Molecule \\
\hline IL-X & Interleukin- $X$ \\
\hline IVC & Inferior vena cava \\
\hline LCR & Locus control region \\
\hline $\mathrm{MCHC}$ & Mean corpuscular hemoglobin concentration \\
\hline NETs & Neutrophil extracellular traps \\
\hline NLR & Nucleotide binding domain-like receptor \\
\hline NO & Nitric oxide \\
\hline PARs & Protease activated receptors \\
\hline PCVs & Packed cell volumes \\
\hline PE & Pulmonary embolism \\
\hline PRR & Pattern recognition receptors \\
\hline PS & Phosphatidylserine \\
\hline RBC & Red blood cells \\
\hline ROS & Reactive oxidative species \\
\hline SAD & $\beta S$-AntillesD-Punjab mice model \\
\hline SCD & Sickle cell disease \\
\hline SS RBCs & Sickle red blood cells \\
\hline TAT & Thrombin-antithrombin complex \\
\hline $\mathrm{TF}$ & Tissue factor \\
\hline TFPI & TF pathway inhibitor \\
\hline TLR & Toll-like receptor \\
\hline $\mathrm{TM}$ & Thrombomodulin \\
\hline TNF- $\alpha$ & Tumor necrosis factor-alpha \\
\hline VCAM & Vascular cell adhesion protein \\
\hline VOCs & Vaso-occlusive crisis \\
\hline VTE & Venous thromboembolism \\
\hline vWF & von Willebrand factor \\
\hline
\end{tabular}

\section{References}

1. Goldhaber, S.Z.; Bounameaux, H. Pulmonary embolism and deep vein thrombosis. Lancet 2012, 379, 1835-1846. [CrossRef]

2. Heit, J.A.; Spencer, F.A.; White, R.H. The epidemiology of venous thromboembolism. J. Thromb. Thrombolysis 2016, 41, 3-14. [CrossRef] [PubMed]

3. Diaz, J.A.; Obi, A.T.; Myers, D.D., Jr.; Wrobleski, S.K.; Henke, P.K.; Mackman, N.; Wakefield, T.W. Critical review of mouse models of venous thrombosis. Arterioscler. Thromb. Vasc. Biol. 2012, 32, 556-562. [CrossRef]

4. Piel, F.B.; Tatem, A.J.; Huang, Z.; Gupta, S.; Williams, T.N.; Weatherall, D.J. Global migration and the changing distribution of sickle haemoglobin: A quantitative study of temporal trends between 1960 and 2000. Lancet Glob. Health 2014, 2, e80-e89. [CrossRef]

5. Ingram, V.M. A specific chemical difference between the globins of normal human and sickle-cell anaemia haemoglobin. Nature 1956, 178, 792-794. [CrossRef]

6. Stuart, M.J.; Nagel, R.L. Sickle-cell disease. Lancet 2004, 364, 1343-1360. [CrossRef]

7. Steinberg, M.H. Sickle cell anemia, the first molecular disease: Overview of molecular etiology, pathophysiology, and therapeutic approaches. Sci. World J. 2008, 8, 1295-1324. [CrossRef] [PubMed] 
8. Kato, G.J.; Piel, F.B.; Reid, C.D.; Gaston, M.H.; Ohene-Frempong, K.; Krishnamurti, L.; Smith, W.R.; Panepinto, J.A.; Weatherall, D.J.; Costa, F.F.; et al. Sickle cell disease. Nat. Rev. Dis. Primers 2018, 4, 18010. [CrossRef]

9. Novelli, E.M.; Huynh, C.; Gladwin, M.T.; Moore, C.G.; Ragni, M.V. Pulmonary embolism in sickle cell disease: A case-control study. J. Thromb. Haemost. 2012, 10, 760-766. [CrossRef]

10. Naik, R.P.; Streiff, M.B.; Haywood, C., Jr.; Nelson, J.A.; Lanzkron, S. Venous thromboembolism in adults with sickle cell disease: A serious and under-recognized complication. Am. J. Med. 2013, 126, 443-449. [CrossRef]

11. Naik, R.P.; Streiff, M.B.; Haywood, C., Jr.; Segal, J.B.; Lanzkron, S. Venous thromboembolism incidence in the Cooperative Study of Sickle Cell Disease. J. Thromb. Haemost. 2014, 12, 2010-2016. [CrossRef] [PubMed]

12. Brunson, A.; Lei, A.; Rosenberg, A.S.; White, R.H.; Keegan, T.; Wun, T. Increased incidence of VTE in sickle cell disease patients: Risk factors, recurrence and impact on mortality. Br. J. Haematol. 2017, 178, 319-326. [CrossRef] [PubMed]

13. Yu, T.T.; Nelson, J.; Streiff, M.B.; Lanzkron, S.; Naik, R.P. Risk factors for venous thromboembolism in adults with hemoglobin SC or Sbeta(+) thalassemia genotypes. Thromb. Res. 2016, 141, 35-38. [CrossRef] [PubMed]

14. Adedeji, M.O.; Cespedes, J.; Allen, K.; Subramony, C.; Hughson, M.D. Pulmonary thrombotic arteriopathy in patients with sickle cell disease. Arch. Pathol. Lab. Med. 2001, 125, 1436-1441. [PubMed]

15. Faes, C.; Ilich, A.; Sotiaux, A.; Sparkenbaugh, E.M.; Henderson, M.W.; Buczek, L.; Beckman, J.D.; Ellsworth, P.; Noubouossie, D.F.; Bhoopat, L.; et al. Red blood cells modulate structure and dynamics of venous clot formation in sickle cell disease. Blood 2019, 133, 2529-2541. [CrossRef] [PubMed]

16. Kassim, A.A.; Galadanci, N.A.; Pruthi, S.; DeBaun, M.R. How I treat and manage strokes in sickle cell disease. Blood 2015, 125, 3401-3410. [CrossRef] [PubMed]

17. Byrnes, J.R.; Wolberg, A.S. New findings on venous thrombogenesis. Hamostaseologie 2017, 37, 25-35. [CrossRef]

18. Wun, T.; Brunson, A. Sickle cell disease: An inherited thrombophilia. Hematol. Am. Soc. Hematol. Educ. Program. 2016, 2016, 640-647. [CrossRef]

19. Shet, A.S.; Wun, T. How I diagnose and treat venous thromboembolism in sickle cell disease. Blood 2018, 132, 1761-1769. [CrossRef]

20. Ataga, K.I.; Moore, C.G.; Hillery, C.A.; Jones, S.; Whinna, H.C.; Strayhorn, D.; Sohier, C.; Hinderliter, A.; Parise, L.V.; Orringer, E.P. Coagulation activation and inflammation in sickle cell disease-associated pulmonary hypertension. Haematologica 2008, 93, 20-26. [CrossRef]

21. Sparkenbaugh, E.; Pawlinski, R. Prothrombotic aspects of sickle cell disease. J. Thromb. Haemost. 2017, 15, 1307-1316. [CrossRef] [PubMed]

22. Tomer, A.; Harker, L.A.; Kasey, S.; Eckman, J.R. Thrombogenesis in sickle cell disease. J. Lab. Clin. Med. 2001, 137, 398-407. [CrossRef] [PubMed]

23. Setty, B.N.; Rao, A.K.; Stuart, M.J. Thrombophilia in sickle cell disease: The red cell connection. Blood 2001, 98, 3228-3233. [CrossRef] [PubMed]

24. Francis, R.B. Platelets, coagulation, and fibrinolysis in sickle cell disease: Their possible role in vascular occlusion. Blood Coagul. Fibrinolysis 1991, 2, 341-353. [CrossRef]

25. Shet, A.S.; Aras, O.; Gupta, K.; Hass, M.J.; Rausch, D.J.; Saba, N.; Koopmeiners, L.; Key, N.S.; Hebbel, R.P. Sickle blood contains tissue factor-positive microparticles derived from endothelial cells and monocytes. Blood 2003, 102, 2678-2683. [CrossRef]

26. Conran, N.; De Paula, E.V. Thromboinflammatory mechanisms in sickle cell disease-challenging the hemostatic balance. Haematologica 2020. [CrossRef]

27. Dentali, F.; Ageno, W.; Bozzato, S.; Malato, A.; Gianni, M.; Squizzato, A.; Prisco, D. Role of factor V Leiden or G20210A prothrombin mutation in patients with symptomatic pulmonary embolism and deep vein thrombosis: A meta-analysis of the literature. J. Thromb. Haemost. 2012, 10, 732-737. [CrossRef]

28. Cleuren, A.C.; van Vlijmen, B.J.; Reitsma, P.H. Transgenic mouse models of venous thrombosis: Fulfilling the expectations? Semin. Thromb. Hemost. 2007, 33, 610-616. [CrossRef]

29. Diaz, J.A.; Saha, P.; Cooley, B.; Palmer, O.R.; Grover, S.P.; Mackman, N.; Wakefield, T.W.; Henke, P.K.; Smith, A.; Lal, B.K. Choosing a Mouse Model of Venous Thrombosis. Arter. Thromb. Vasc. Biol. 2019, 39, 311-318. [CrossRef]

30. Fabry, M.E. Transgenic animal models of sickle cell disease. Experientia 1993, 49, 28-36. [CrossRef]

31. Beuzard, Y. Mouse models of sickle cell disease. Transfus. Clin. Biol. 2008, 15, 7-11. [CrossRef] [PubMed] 
32. Belcher, J.D.; Bryant, C.J.; Nguyen, J.; Bowlin, P.R.; Kielbik, M.C.; Bischof, J.C.; Hebbel, R.P.; Vercellotti, G.M. Transgenic sickle mice have vascular inflammation. Blood 2003, 101, 3953-3959. [CrossRef] [PubMed]

33. Kaul, D.K.; Hebbel, R.P. Hypoxia/reoxygenation causes inflammatory response in transgenic sickle mice but not in normal mice. J. Clin. Investig. 2000, 106, 411-420. [CrossRef] [PubMed]

34. Aufradet, E.; DeSouza, G.; Bourgeaux, V.; Bessaad, A.; Campion, Y.; Canet-Soulas, E.; Pialoux, V.; Chirico, E.N.; Chevrier, A.M.; Godfrin, Y.; et al. Hypoxia/reoxygenation stress increases markers of vaso-occlusive crisis in sickle SAD mice. Clin. Hemorheol. Microcirc. 2013, 54, 297-312. [CrossRef] [PubMed]

35. Pritchard, K.A., Jr.; Ou, J.; Ou, Z.; Shi, Y.; Franciosi, J.P.; Signorino, P.; Kaul, S.; Ackland-Berglund, C.; Witte, K.; Holzhauer, S.; et al. Hypoxia-induced acute lung injury in murine models of sickle cell disease. Am. J. Physiol. Lung Cell Mol. Physiol. 2004, 286, L705-L714. [CrossRef] [PubMed]

36. Paszty, C.; Brion, C.M.; Manci, E.; Witkowska, H.E.; Stevens, M.E.; Mohandas, N.; Rubin, E.M. Transgenic knockout mice with exclusively human sickle hemoglobin and sickle cell disease. Science 1997, 278, 876-878. [CrossRef] [PubMed]

37. Ryan, T.M.; Ciavatta, D.J.; Townes, T.M. Knockout-transgenic mouse model of sickle cell disease. Science 1997, 278, 873-876. [CrossRef]

38. Gavins, F.N.; Russell, J.; Senchenkova, E.L.; De Almeida Paula, L.; Damazo, A.S.; Esmon, C.T.; Kirchhofer, D.; Hebbel, R.P.; Granger, D.N. Mechanisms of enhanced thrombus formation in cerebral microvessels of mice expressing hemoglobin-S. Blood 2011, 117, 4125-4133. [CrossRef]

39. Chantrathammachart, P.; Mackman, N.; Sparkenbaugh, E.; Wang, J.G.; Parise, L.V.; Kirchhofer, D.; Key, N.S.; Pawlinski, R. Tissue factor promotes activation of coagulation and inflammation in a mouse model of sickle cell disease. Blood 2012, 120, 636-646. [CrossRef]

40. Sparkenbaugh, E.M.; Chantrathammachart, P.; Wang, S.; Jonas, W.; Kirchhofer, D.; Gailani, D.; Gruber, A.; Kasthuri, R.; Key, N.S.; Mackman, N.; et al. Excess of heme induces tissue factor-dependent activation of coagulation in mice. Haematologica 2015, 100, 308-314. [CrossRef]

41. Guo, Y.; Uy, T.; Wandersee, N.; Scott, P.; Weiler, H.; Holzhauer, S.; Retherford, D.; Foster, T.; Hillery, C. The protein $C$ pathway in human and murine sicjle cell disease: Alterations in protein $C$, thrombomodulin (TM), and endothelial protein $C$ receptor (EPCR) at baseline and during acuste vaso-occlusion. Blood 2016, 112, 538. [CrossRef]

42. Solovey, A.; Kollander, R.; Shet, A.; Milbauer, L.C.; Choong, S.; Panoskaltsis-Mortari, A.; Blazar, B.R.; Kelm, R.J., Jr.; Hebbel, R.P. Endothelial cell expression of tissue factor in sickle mice is augmented by hypoxia/reoxygenation and inhibited by lovastatin. Blood 2004, 104, 840-846. [CrossRef] [PubMed]

43. Grover, S.P.; Mackman, N. Tissue Factor: An Essential Mediator of Hemostasis and Trigger of Thrombosis. Arterioscler. Thromb. Vasc. Biol. 2018, 38, 709-725. [CrossRef] [PubMed]

44. Giesen, P.L.; Rauch, U.; Bohrmann, B.; Kling, D.; Roque, M.; Fallon, J.T.; Badimon, J.J.; Himber, J.; Riederer, M.A.; Nemerson, Y. Blood-borne tissue factor: Another view of thrombosis. Proc. Natl. Acad. Sci. USA 1999, 96, 2311-2315. [CrossRef] [PubMed]

45. Furie, B.; Furie, B.C. Mechanisms of thrombus formation. N. Engl. J. Med. 2008, 359, 938-949. [CrossRef] [PubMed]

46. Day, S.M.; Reeve, J.L.; Pedersen, B.; Farris, D.M.; Myers, D.D.; Im, M.; Wakefield, T.W.; Mackman, N.; Fay, W.P. Macrovascular thrombosis is driven by tissue factor derived primarily from the blood vessel wall. Blood 2005, 105, 192-198. [CrossRef]

47. Yan, S.F.; Zou, Y.S.; Gao, Y.; Zhai, C.; Mackman, N.; Lee, S.L.; Milbrandt, J.; Pinsky, D.; Kisiel, W.; Stern, D. Tissue factor transcription driven by Egr-1 is a critical mechanism of murine pulmonary fibrin deposition in hypoxia. Proc. Natl. Acad. Sci. USA 1998, 95, 8298-8303. [CrossRef]

48. Lawson, C.A.; Yan, S.D.; Yan, S.F.; Liao, H.; Zhou, Y.S.; Sobel, J.; Kisiel, W.; Stern, D.M.; Pinsky, D.J. Monocytes and tissue factor promote thrombosis in a murine model of oxygen deprivation. J. Clin. Investig. 1997, 99, 1729-1738. [CrossRef]

49. Setty, B.N.; Betal, S.G.; Zhang, J.; Stuart, M.J. Heme induces endothelial tissue factor expression: Potential role in hemostatic activation in patients with hemolytic anemia. J. Thromb. Haemost. 2008, 6, 2202-2209. [CrossRef]

50. Solovey, A.; Gui, L.; Key, N.S.; Hebbel, R.P. Tissue factor expression by endothelial cells in sickle cell anemia. J. Clin. Investig. 1998, 101, 1899-1904. [CrossRef] 
51. Key, N.S.; Slungaard, A.; Dandelet, L.; Nelson, S.C.; Moertel, C.; Styles, L.A.; Kuypers, F.A.; Bach, R.R. Whole blood tissue factor procoagulant activity is elevated in patients with sickle cell disease. Blood 1998, 91, 4216-4223. [CrossRef]

52. Hrachovinova, I.; Cambien, B.; Hafezi-Moghadam, A.; Kappelmayer, J.; Camphausen, R.T.; Widom, A.; Xia, L.; Kazazian, H.H., Jr.; Schaub, R.G.; McEver, R.P.; et al. Interaction of P-selectin and PSGL-1 generates microparticles that correct hemostasis in a mouse model of hemophilia A. Nat. Med. 2003, 9, 1020-1025. [CrossRef] [PubMed]

53. Thomas, G.M.; Brill, A.; Mezouar, S.; Crescence, L.; Gallant, M.; Dubois, C.; Wagner, D.D. Tissue factor expressed by circulating cancer cell-derived microparticles drastically increases the incidence of deep vein thrombosis in mice. J. Thromb. Haemost. 2015, 13, 1310-1319. [CrossRef] [PubMed]

54. Gross, P.L.; Furie, B.C.; Merrill-Skoloff, G.; Chou, J.; Furie, B. Leukocyte-versus microparticle-mediated tissue factor transfer during arteriolar thrombus development. J. Leukoc. Biol. 2005, 78, 1318-1326. [CrossRef] [PubMed]

55. Geddings, J.E.; Hisada, Y.; Boulaftali, Y.; Getz, T.M.; Whelihan, M.; Fuentes, R.; Dee, R.; Cooley, B.C.; Key, N.S.; Wolberg, A.S.; et al. Tissue factor-positive tumor microvesicles activate platelets and enhance thrombosis in mice. J. Thromb. Haemost. 2016, 14, 153-166. [CrossRef]

56. Witkowski, M.; Landmesser, U.; Rauch, U. Tissue factor as a link between inflammation and coagulation. Trends Cardiovasc Med. 2016, 26, 297-303. [CrossRef] [PubMed]

57. Sparkenbaugh, E.M.; Chantrathammachart, P.; Mickelson, J.; van Ryn, J.; Hebbel, R.P.; Monroe, D.M.; Mackman, N.; Key, N.S.; Pawlinski, R. Differential contribution of FXa and thrombin to vascular inflammation in a mouse model of sickle cell disease. Blood 2014, 123, 1747-1756. [CrossRef]

58. Sparkenbaugh, E.M.; Chantrathammachart, P.; Chandarajoti, K.; Mackman, N.; Key, N.S.; Pawlinski, R. Thrombin-independent contribution of tissue factor to inflammation and cardiac hypertrophy in a mouse model of sickle cell disease. Blood 2016, 127, 1371-1373. [CrossRef]

59. Muller, F.; Mutch, N.J.; Schenk, W.A.; Smith, S.A.; Esterl, L.; Spronk, H.M.; Schmidbauer, S.; Gahl, W.A.; Morrissey, J.H.; Renne, T. Platelet polyphosphates are proinflammatory and procoagulant mediators in vivo. Cell 2009, 139, 1143-1156. [CrossRef]

60. Sparkenbaugh, E.F.C.; Noubouossie, D.; Kirchhofer, D.K.; Gruber, A.; Key, N.; Rafal, P. FXIIa differentially regulates thrombin generation during steady state and vaso-occlusive crisis in sickle cell mice. Blood 2016, 128, 162. [CrossRef]

61. Hebbel, R.P.; Belcher, J.D.; Vercellotti, G.M. The multifaceted role of ischemia/reperfusion in sickle cell anemia. J. Clin. Investig. 2020, 130, 1062-1072. [CrossRef] [PubMed]

62. Pfeiler, S.; Stark, K.; Massberg, S.; Engelmann, B. Propagation of thrombosis by neutrophils and extracellular nucleosome networks. Haematologica 2017, 102, 206-213. [CrossRef] [PubMed]

63. Jansen, M.P.; Emal, D.; Teske, G.J.; Dessing, M.C.; Florquin, S.; Roelofs, J.J. Release of extracellular DNA influences renal ischemia reperfusion injury by platelet activation and formation of neutrophil extracellular traps. Kidney Int. 2017, 91, 352-364. [CrossRef]

64. Noubouossie, D.F.; Whelihan, M.F.; Yu, Y.B.; Sparkenbaugh, E.; Pawlinski, R.; Monroe, D.M.; Key, N.S. In vitro activation of coagulation by human neutrophil DNA and histone proteins but not neutrophil extracellular traps. Blood 2017, 129, 1021-1029. [CrossRef] [PubMed]

65. De Franceschi, L.; Baron, A.; Scarpa, A.; Adrie, C.; Janin, A.; Barbi, S.; Kister, J.; Rouyer-Fessard, P.; Corrocher, R.; Leboulch, P.; et al. Inhaled nitric oxide protects transgenic SAD mice from sickle cell disease-specific lung injury induced by hypoxia/reoxygenation. Blood 2003, 102, 1087-1096. [CrossRef] [PubMed]

66. Noubouossie, D.; Key, N.S.; Ataga, K.I. Coagulation abnormalities of sickle cell disease: Relationship with clinical outcomes and the effect of disease modifying therapies. Blood Rev. 2016, 30, 245-256. [CrossRef]

67. Hogan, K.A.; Weiler, H.; Lord, S.T. Mouse models in coagulation. Thromb. Haemost. 2002, 87, 563-574. [CrossRef]

68. Arumugam, P.I.; Mullins, E.S.; Shanmukhappa, S.K.; Monia, B.P.; Loberg, A.; Shaw, M.A.; Rizvi, T.; Wansapura, J.; Degen, J.L.; Malik, P. Genetic diminution of circulating prothrombin ameliorates multiorgan pathologies in sickle cell disease mice. Blood 2015, 126, 1844-1855. [CrossRef] 
69. Sparkenbaugh, E.M.; Chen, C.; Brzoska, T.; Nguyen, J.; Wang, S.; Vercellotti, G.M.; Key, N.S.; Sundd, P.; Belcher, J.D.; Pawlinski, R. Thrombin-mediated activation of PAR-1 contributes to microvascular stasis in mouse models of sickle cell disease. Blood 2020. [CrossRef]

70. Reiter, C.D.; Wang, X.; Tanus-Santos, J.E.; Hogg, N.; Cannon, R.O.; Schechter, A.N.; Gladwin, M.T. Cell-free hemoglobin limits nitric oxide bioavailability in sickle-cell disease. Nat. Med. 2002, 8, 1383-1389. [CrossRef]

71. Morris, C.R.; Kato, G.J.; Poljakovic, M.; Wang, X.; Blackwelder, W.C.; Sachdev, V.; Hazen, S.L.; Vichinsky, E.P.; Morris, S.M., Jr.; Gladwin, M.T. Dysregulated arginine metabolism, hemolysis-associated pulmonary hypertension, and mortality in sickle cell disease. JAMA 2005, 294, 81-90. [CrossRef] [PubMed]

72. De Franceschi, L.; Cappellini, M.D.; Olivieri, O. Thrombosis and sickle cell disease. Semin. Thromb. Hemost. 2011, 37, 226-236. [CrossRef] [PubMed]

73. Hagger, D.; Wolff, S.; Owen, J.; Samson, D. Changes in coagulation and fibrinolysis in patients with sickle cell disease compared with healthy black controls. Blood Coagul. Fibrinolysis 1995, 6, 93-99. [CrossRef] [PubMed]

74. Esmon, C.T. Role of coagulation inhibitors in inflammation. Thromb. Haemost. 2001, 86, 51-56. [CrossRef] [PubMed]

75. Jackson, S.P.; Darbousset, R.; Schoenwaelder, S.M. Thromboinflammation: Challenges of therapeutically targeting coagulation and other host defense mechanisms. Blood 2019, 133, 906-918. [CrossRef]

76. Takeuchi, O.; Akira, S. Pattern recognition receptors and inflammation. Cell 2010, 140, 805-820. [CrossRef] [PubMed]

77. Mendonca, R.; Silveira, A.A.; Conran, N. Red cell DAMPs and inflammation. Inflamm. Res. 2016, 65, 665-678. [CrossRef]

78. Stark, K.; Philippi, V.; Stockhausen, S.; Busse, J.; Antonelli, A.; Miller, M.; Schubert, I.; Hoseinpour, P.; Chandraratne, S.; von Bruhl, M.L.; et al. Disulfide HMGB1 derived from platelets coordinates venous thrombosis in mice. Blood 2016, 128, 2435-2449. [CrossRef]

79. Yadav, V.; Chi, L.; Zhao, R.; Tourdot, B.E.; Yalavarthi, S.; Jacobs, B.N.; Banka, A.; Liao, H.; Koonse, S.; Anyanwu, A.C.; et al. Ectonucleotidase tri(di)phosphohydrolase-1 (ENTPD-1) disrupts inflammasome/interleukin 1beta-driven venous thrombosis. J. Clin. Investig. 2019, 129, 2872-2877. [CrossRef]

80. Sundd, P.; Gladwin, M.T.; Novelli, E.M. Pathophysiology of Sickle Cell Disease. Annu. Rev. Pathol. 2019, 14, 263-292. [CrossRef]

81. Ansari, J.; Gavins, F.N.E. Ischemia-Reperfusion Injury in Sickle Cell Disease: From Basics to Therapeutics. Am. J. Pathol. 2019, 189, 706-718. [CrossRef] [PubMed]

82. Belcher, J.D.; Chen, C.; Nguyen, J.; Milbauer, L.; Abdulla, F.; Alayash, A.I.; Smith, A.; Nath, K.A.; Hebbel, R.P.; Vercellotti, G.M. Heme triggers TLR4 signaling leading to endothelial cell activation and vaso-occlusion in murine sickle cell disease. Blood 2014, 123, 377-390. [CrossRef] [PubMed]

83. Merle, N.S.; Paule, R.; Leon, J.; Daugan, M.; Robe-Rybkine, T.; Poillerat, V.; Torset, C.; Fremeaux-Bacchi, V.; Dimitrov, J.D.; Roumenina, L.T. P-selectin drives complement attack on endothelium during intravascular hemolysis in TLR-4/heme-dependent manner. Proc. Natl. Acad. Sci. USA 2019, 116, 6280-6285. [CrossRef] [PubMed]

84. Silveira, A.A.A.; Mahon, O.R.; Cunningham, C.C.; Corr, E.M.; Mendonca, R.; Saad, S.T.O.; Costa, F.F.; Dunne, A.; Conran, N. S100A8 acts as an autocrine priming signal for heme-induced human Mvarphi pro-inflammatory responses in hemolytic inflammation. J. Leukoc. Biol. 2019, 106, 35-43. [CrossRef] [PubMed]

85. Jana, S.; Strader, M.B.; Meng, F.; Hicks, W.; Kassa, T.; Tarandovskiy, I.; De Paoli, S.; Simak, J.; Heaven, M.R.; Belcher, J.D.; et al. Hemoglobin oxidation-dependent reactions promote interactions with band 3 and oxidative changes in sickle cell-derived microparticles. JCI Insight 2018, 3. [CrossRef]

86. Camus, S.M.; De Moraes, J.A.; Bonnin, P.; Abbyad, P.; Le Jeune, S.; Lionnet, F.; Loufrani, L.; Grimaud, L.; Lambry, J.C.; Charue, D.; et al. Circulating cell membrane microparticles transfer heme to endothelial cells and trigger vasoocclusions in sickle cell disease. Blood 2015, 125, 3805-3814. [CrossRef] [PubMed]

87. Solovey, A.; Somani, A.; Belcher, J.D.; Milbauer, L.; Vincent, L.; Pawlinski, R.; Nath, K.A.; Kelm, R.J., Jr.; Mackman, N.; O'Sullivan, M.G.; et al. A monocyte-TNF-endothelial activation axis in sickle transgenic mice: Therapeutic benefit from TNF blockade. Am. J. Hematol. 2017, 92, 1119-1130. [CrossRef] 
88. Vats, R.; Brzoska, T.; Bennewitz, M.F.; Jimenez, M.A.; Pradhan-Sundd, T.; Tutuncuoglu, E.; Jonassaint, J.; Gutierrez, E.; Watkins, S.C.; Shiva, S.; et al. Platelet Extracellular Vesicles Drive Inflammasome-IL-1beta-Dependent Lung Injury in Sickle Cell Disease. Am. J. Respir. Crit. Care Med. 2020, 201, 33-46. [CrossRef]

89. Vogel, S.; Arora, T.; Wang, X.; Mendelsohn, L.; Nichols, J.; Allen, D.; Shet, A.S.; Combs, C.A.; Quezado, Z.M.N.; Thein, S.L. The platelet NLRP3 inflammasome is upregulated in sickle cell disease via HMGB1/TLR4 and Bruton tyrosine kinase. Blood Adv. 2018, 2, 2672-2680. [CrossRef]

90. Merle, N.S.; Grunenwald, A.; Rajaratnam, H.; Gnemmi, V.; Frimat, M.; Figueres, M.L.; Knockaert, S.; Bouzekri, S.; Charue, D.; Noe, R.; et al. Intravascular hemolysis activates complement via cell-free heme and heme-loaded microvesicles. JCI Insight 2018, 3. [CrossRef]

91. Vercellotti, G.M.; Dalmasso, A.P.; Schaid, T.R., Jr.; Nguyen, J.; Chen, C.; Ericson, M.E.; Abdulla, F.; Killeen, T.; Lindorfer, M.A.; Taylor, R.P.; et al. Critical role of C5a in sickle cell disease. Am. J. Hematol. 2019, 94, 327-337. [CrossRef] [PubMed]

92. Subramaniam, S.; Jurk, K.; Hobohm, L.; Jackel, S.; Saffarzadeh, M.; Schwierczek, K.; Wenzel, P.; Langer, F.; Reinhardt, C.; Ruf, W. Distinct contributions of complement factors to platelet activation and fibrin formation in venous thrombus development. Blood 2017, 129, 2291-2302. [CrossRef] [PubMed]

93. Santiago, R.P.; Guarda, C.C.; Figueiredo, C.V.B.; Fiuza, L.M.; Aleluia, M.M.; Adanho, C.S.A.; Carvalho, M.O.S.; Pitanga, T.N.; Zanette, D.L.; Lyra, I.M.; et al. Serum haptoglobin and hemopexin levels are depleted in pediatric sickle cell disease patients. Blood Cells Mol. Dis. 2018, 72, 34-36. [CrossRef] [PubMed]

94. Belcher, J.D.; Chen, C.; Nguyen, J.; Abdulla, F.; Zhang, P.; Nguyen, H.; Nguyen, P.; Killeen, T.; Miescher, S.M.; Brinkman, N.; et al. Haptoglobin and hemopexin inhibit vaso-occlusion and inflammation in murine sickle cell disease: Role of heme oxygenase-1 induction. PLoS ONE 2018, 13, e0196455. [CrossRef] [PubMed]

95. Wang, H.; Luo, W.; Wang, J.; Guo, C.; Wolffe, S.L.; Wang, J.; Sun, E.B.; Bradley, K.N.; Campbell, A.D.; Eitzman, D.T. Paradoxical protection from atherosclerosis and thrombosis in a mouse model of sickle cell disease. Br. J. Haematol. 2013, 162, 120-129. [CrossRef] [PubMed]

96. Lv, B.; Wang, H.; Tang, Y.; Fan, Z.; Xiao, X.; Chen, F. High-mobility group box 1 protein induces tissue factor expression in vascular endothelial cells via activation of NF-kappaB and Egr-1. Thromb. Haemost. 2009, 102, 352-359. [CrossRef]

97. Xu, H.; Wandersee, N.J.; Guo, Y.; Jones, D.W.; Holzhauer, S.L.; Hanson, M.S.; Machogu, E.; Brousseau, D.C.; Hogg, N.; Densmore, J.C.; et al. Sickle cell disease increases high mobility group box 1: A novel mechanism of inflammation. Blood 2014, 124, 3978-3981. [CrossRef]

98. Chen, G.; Zhang, D.; Fuchs, T.A.; Manwani, D.; Wagner, D.D.; Frenette, P.S. Heme-induced neutrophil extracellular traps contribute to the pathogenesis of sickle cell disease. Blood 2014, 123, 3818-3827. [CrossRef]

99. Thalin, C.; Hisada, Y.; Lundstrom, S.; Mackman, N.; Wallen, H. Neutrophil Extracellular Traps: Villains and Targets in Arterial, Venous, and Cancer-Associated Thrombosis. Arter. Thromb. Vasc. Biol. 2019, 39, 1724-1738. [CrossRef]

100. Von Bruhl, M.L.; Stark, K.; Steinhart, A.; Chandraratne, S.; Konrad, I.; Lorenz, M.; Khandoga, A.; Tirniceriu, A.; Coletti, R.; Kollnberger, M.; et al. Monocytes, neutrophils, and platelets cooperate to initiate and propagate venous thrombosis in mice in vivo. J. Exp. Med. 2012, 209, 819-835. [CrossRef]

101. Fuchs, T.A.; Brill, A.; Duerschmied, D.; Schatzberg, D.; Monestier, M.; Myers, D.D., Jr.; Wrobleski, S.K.; Wakefield, T.W.; Hartwig, J.H.; Wagner, D.D. Extracellular DNA traps promote thrombosis. Proc. Natl. Acad. Sci. USA 2010, 107, 15880-15885. [CrossRef]

102. Nasimuzzaman, M.; Malik, P. Role of the coagulation system in the pathogenesis of sickle cell disease. Blood Adv. 2019, 3, 3170-3180. [CrossRef] [PubMed]

103. Wun, T.; Paglieroni, T.; Tablin, F.; Welborn, J.; Nelson, K.; Cheung, A. Platelet activation and platelet-erythrocyte aggregates in patients with sickle cell anemia. J. Lab. Clin. Med. 1997, 129, 507-516. [CrossRef]

104. Wun, T.; Paglieroni, T.; Rangaswami, A.; Franklin, P.H.; Welborn, J.; Cheung, A.; Tablin, F. Platelet activation in patients with sickle cell disease. Br. J. Haematol. 1998, 100, 741-749. [CrossRef] [PubMed]

105. Wun, T.; Cordoba, M.; Rangaswami, A.; Cheung, A.W.; Paglieroni, T. Activated monocytes and platelet-monocyte aggregates in patients with sickle cell disease. Clin. Lab. Haematol. 2002, 24, 81-88. [CrossRef] [PubMed] 
106. Polanowska-Grabowska, R.; Wallace, K.; Field, J.J.; Chen, L.; Marshall, M.A.; Figler, R.; Gear, A.R.; Linden, J. P-selectin-mediated platelet-neutrophil aggregate formation activates neutrophils in mouse and human sickle cell disease. Arter. Thromb. Vasc. Biol. 2010, 30, 2392-2399. [CrossRef] [PubMed]

107. Hidalgo, A.; Chang, J.; Jang, J.-E.; Peired, A.J.; Chiang, E.Y.; Frenette, P.S. Heterotypic interactions enabled by polarized neutrophil microdomains mediate thromboinflammatory injury. Nat. Med. 2009, 15, 384-391. [CrossRef]

108. Freedman, M.L.; Karpatkin, S. Elevated platelet count and megathrombocyte number in sickle cell anemia. Blood 1975, 46, 579-582. [CrossRef]

109. Shet, A.S.; Hoffmann, T.J.; Jirouskova, M.; Janczak, C.A.; Stevens, J.R.; Adamson, A.; Mohandas, N.; Manci, E.A.; Cynober, T.; Coller, B.S. Morphological and functional platelet abnormalities in Berkeley sickle cell mice. Blood Cells Mol. Dis. 2008, 41, 109-118. [CrossRef]

110. Annarapu, G.K.; Singhal, R.; Gupta, A.; Chawla, S.; Batra, H.; Seth, T.; Guchhait, P. HbS Binding to GP1balpha Activates Platelets in Sickle Cell Disease. PLoS ONE 2016, 11, e0167899. [CrossRef]

111. Semeraro, F.; Ammollo, C.T.; Morrissey, J.H.; Dale, G.L.; Friese, P.; Esmon, N.L.; Esmon, C.T. Extracellular histones promote thrombin generation through platelet-dependent mechanisms: Involvement of platelet TLR2 and TLR4. Blood 2011, 118, 1952-1961. [CrossRef] [PubMed]

112. O’Brien, J.; Duncan, H.; Kirsh, G.; Allen, V.; King, P.; Hargraves, R.; Mendes, L.; Perera, T.; Catto, P.; Schofield, S. Prevention of pulmonary embolism and deep vein thrombosis with low dose aspirin: Pulmonary Embolism Prevention (PEP) trial. Lancet 2000, 355, 1295-1302.

113. Anea, C.B.; Lyon, M.; Lee, I.A.; Gonzales, J.N.; Adeyemi, A.; Falls, G.; Kutlar, A.; Brittain, J.E. Pulmonary platelet thrombi and vascular pathology in acute chest syndrome in patients with sickle cell disease. Am. J. Hematol. 2016, 91, 173-178. [CrossRef] [PubMed]

114. Bennewitz, M.F.; Jimenez, M.A.; Vats, R.; Tutuncuoglu, E.; Jonassaint, J.; Kato, G.J.; Gladwin, M.T.; Sundd, P. Lung vaso-occlusion in sickle cell disease mediated by arteriolar neutrophil-platelet microemboli. JCI Insight 2017, 2, e89761. [CrossRef]

115. Cines, D.B.; Pollak, E.S.; Buck, C.A.; Loscalzo, J.; Zimmerman, G.A.; McEver, R.P.; Pober, J.S.; Wick, T.M.; Konkle, B.A.; Schwartz, B.S.; et al. Endothelial cells in physiology and in the pathophysiology of vascular disorders. Blood 1998, 91, 3527-3561.

116. Folsom, A.R.; Tang, W.; Roetker, N.S.; Kshirsagar, A.V.; Derebail, V.K.; Lutsey, P.L.; Naik, R.; Pankow, J.S.; Grove, M.L.; Basu, S.; et al. Prospective study of sickle cell trait and venous thromboembolism incidence. J. Thromb. Haemost. 2015, 13, 2-9. [CrossRef]

117. Payne, H.; Ponomaryov, T.; Watson, S.P.; Brill, A. Mice with a deficiency in CLEC-2 are protected against deep vein thrombosis. Blood 2017, 129, 2013-2020. [CrossRef]

118. Kaul, D.K.; Fabry, M.E.; Costantini, F.; Rubin, E.M.; Nagel, R.L. In vivo demonstration of red cell-endothelial interaction, sickling and altered microvascular response to oxygen in the sickle transgenic mouse. J. Clin. Investig. 1995, 96, 2845-2853. [CrossRef]

119. Solovey, A.; Lin, Y.; Browne, P.; Choong, S.; Wayner, E.; Hebbel, R.P. Circulating activated endothelial cells in sickle cell anemia. N. Engl. J. Med. 1997, 337, 1584-1590. [CrossRef]

120. Bennewitz, M.F.; Tutuncuoglu, E.; Gudapati, S.; Brzoska, T.; Watkins, S.C.; Monga, S.P.; Pradhan-Sundd, T.; Sundd, P. P-selectin-deficient mice to study pathophysiology of sickle cell disease. Blood Adv. 2020, 4, 266-273. [CrossRef]

121. Wood, K.C.; Hebbel, R.P.; Granger, D.N. Endothelial Cell P-selectin Mediates a Proinflammatory and Prothrombogenic Phenotype in Cerebral Venules of Sickle Cell Transgenic Mice. Am. J. Physiol. Heart Circ. Physiol. 2004, 286, H1608-H1614. [CrossRef] [PubMed]

122. Embury, S.H.; Matsui, N.M.; Ramanujam, S.; Mayadas, T.N.; Noguchi, C.T.; Diwan, B.A.; Mohandas, N.; Cheung, A.T. The contribution of endothelial cell P-selectin to the microvascular flow of mouse sickle erythrocytes in vivo. Blood 2004, 104, 3378-3385. [CrossRef] [PubMed]

123. Myers, D., Jr.; Farris, D.; Hawley, A.; Wrobleski, S.; Chapman, A.; Stoolman, L.; Knibbs, R.; Strieter, R.; Wakefield, T. Selectins influence thrombosis in a mouse model of experimental deep venous thrombosis. J. Surg. Res. 2002, 108, 212-221. [CrossRef]

124. Ataga, K.I.; Kutlar, A.; Kanter, J.; Liles, D.; Cancado, R.; Friedrisch, J.; Guthrie, T.H.; Knight-Madden, J.; Alvarez, O.A.; Gordeuk, V.R.; et al. Crizanlizumab for the Prevention of Pain Crises in Sickle Cell Disease. N. Engl. J. Med. 2017, 376, 429-439. [CrossRef] [PubMed] 
125. Telen, M.J.; Malik, P.; Vercellotti, G.M. Therapeutic strategies for sickle cell disease: Towards a multi-agent approach. Nat. Rev. Drug Discov. 2019, 18, 139-158. [CrossRef] [PubMed]

126. Brooks, E.G.; Trotman, W.; Wadsworth, M.P.; Taatjes, D.J.; Evans, M.F.; Ittleman, F.P.; Callas, P.W.; Esmon, C.T.; Bovill, E.G. Valves of the deep venous system: An overlooked risk factor. Blood 2009, 114, 1276-1279. [CrossRef] [PubMed]

127. Byrnes, J.R.; Wolberg, A.S. Red blood cells in thrombosis. Blood 2017, 130, 1795-1799. [CrossRef]

128. Klatt, C.; Kruger, I.; Zey, S.; Krott, K.J.; Spelleken, M.; Gowert, N.S.; Oberhuber, A.; Pfaff, L.; Luckstadt, W.; Jurk, K.; et al. Platelet-RBC interaction mediated by FasL/FasR induces procoagulant activity important for thrombosis. J. Clin. Investig. 2018, 128, 3906-3925. [CrossRef]

129. Ogunsile, F.J.; Naik, R.; Lanzkron, S. Overcoming challenges of venous thromboembolism in sickle cell disease treatment. Expert Rev. Hematol. 2019, 12, 173-182. [CrossRef]

130. Guy, A.; Gourdou-Latyszenok, V.; Le Lay, N.; Peghaire, C.; Kilani, B.; Dias, J.V.; Duplaa, C.; Renault, M.A.; Denis, C.; Villeval, J.L.; et al. Vascular endothelial cell expression of JAK2(V617F) is sufficient to promote a pro-thrombotic state due to increased P-selectin expression. Haematologica 2019, 104, 70-81. [CrossRef]

131. Perner, F.; Perner, C.; Ernst, T.; Heidel, F.H. Roles of JAK2 in Aging, Inflammation, Hematopoiesis and Malignant Transformation. Cells 2019, 8, 854. [CrossRef] [PubMed]

132. Connors, J.M.; Levy, J.H. COVID-19 and its implications for thrombosis and anticoagulation. Blood 2020. [CrossRef] [PubMed]

(C) 2020 by the authors. Licensee MDPI, Basel, Switzerland. This article is an open access article distributed under the terms and conditions of the Creative Commons Attribution (CC BY) license (http://creativecommons.org/licenses/by/4.0/). 